\title{
Dietary protein and bone health
}

\author{
Fiona Ginty \\ MRC Human Nutrition Research, The Elsie Widdowson Laboratory, Fulbourn Road, Cambridge CB1 9NL, UK
}

\begin{abstract}
The effects of dietary protein on bone health are paradoxical and need to be considered in context of the age, health status and usual diet of the population. Over the last 80 years numerous studies have demonstrated that a high protein intake increases urinary $\mathrm{Ca}$ excretion and that on average $1 \mathrm{mg} \mathrm{Ca}$ is lost in urine for every $1 \mathrm{~g}$ rise in dietary protein. This relationship is primarily attributable to metabolism of $\mathrm{S}$ amino acids present in animal and some vegetable proteins, resulting in a greater acid load and buffering response by the skeleton. However, many of these early studies that demonstrated the calciuric effects of protein were limited by low subject numbers, methodological errors and the use of high doses of purified forms of protein. Furthermore, the cross-cultural and population studies that showed a positive association between animal-protein intake and hip fracture risk did not consider other lifestyle or dietary factors that may protect or increase the risk of fracture. The effects of protein on bone appear to be biphasic and may also depend on intake of $\mathrm{Ca}$ - and alkali-rich foods, such as fruit and vegetables. At low protein intakes insulin-like growth factor production is reduced, which in turn has a negative effect on $\mathrm{Ca}$ and phosphate metabolism, bone formation and muscle cell synthesis. Although growth and skeletal development is impaired at very low protein intakes, it is not known whether variations in protein quality affect the achievement of optimal peak bone mass in adolescents and young adults. Prospective studies in the elderly in the USA have shown that the greatest bone losses occur in elderly men and women with an average protein intake of $16-50 \mathrm{~g} / \mathrm{d}$. Although a low protein intake may be indicative of a generally poorer diet and state of health, there is a need to evaluate whether there is a lower threshold for protein intake in the elderly in Europe that may result in increased bone loss and risk of osteoporotic fracture.
\end{abstract}

Dietary protein: Calcium metabolism: Insulin-like growth factor 1: Osteoporosis: Bone health

Over the last 80 years research into the importance of dietary protein for bone health has been dominated by a focus on the potential negative effects. Intervention studies have shown that a higher protein intake is associated with increased urinary $\mathrm{Ca}$ excretion, and cross-sectional and prospective population studies have demonstrated a link between a high protein intake and a greater risk of fracture. A paradox emerges with more recent evidence that a higher protein intake may actually benefit bone health by reducing bone loss and fracture risk in older adults. The present review will attempt to summarise and re-evaluate the earlier evidence for the negative effects of protein on bone health, and identify some of the issues that might affect the interpretation of the earlier findings. It will also address the more recent evidence on the positive effects of protein on bone health and identify some areas of research that may permit a clearer consensus to be reached.

\section{Mechanistic basis for the calciuric effects of protein}

Hepatic oxidation of the S-containing amino acids methionine and cysteine to $\mathrm{H}_{2} \mathrm{SO}_{4}$ and the consequent reduction in blood $\mathrm{pH}$ is thought to be the primary mechanism by which bone resorption is increased and urinary $\mathrm{Ca}$ losses occur in response to a higher dietary protein intake (Remer, 2000; Fig. 1). There is a misconception that animal protein (i.e. meat, eggs and dairy products) is the primary source of $\mathrm{S}$ amino acids, but nuts and cereals are also important sources (Paul et al. 1980; Oh, 2000; Table 1). The $\mathrm{P}$ and chloride content of the diet also determine the dietary acid load. However, the potential of the dietary acid load to increase bone resorption and urinary $\mathrm{Ca}$ excretion depends in part on the dietary alkali load (K, $\mathrm{Na}, \mathrm{Ca}$ and $\mathrm{Mg})$, which has been shown to neutralise the $\mathrm{pH}$-lowering effects of a higher dietary acid load (Buclin et al. 2001). The dietary 


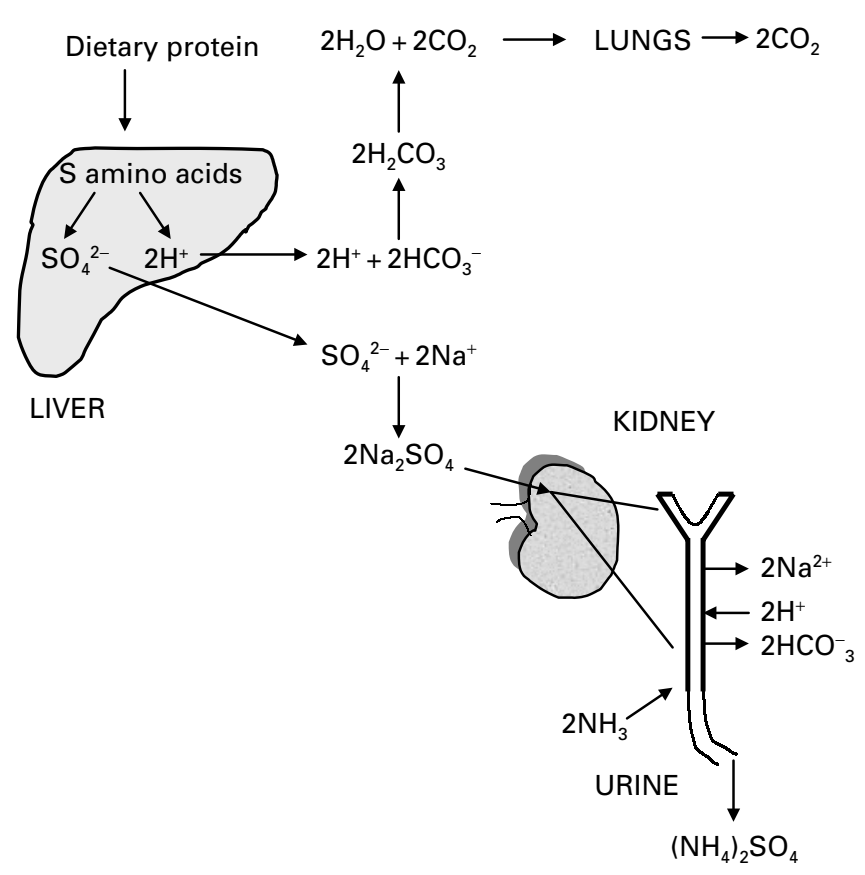

Fig. 1. The hepatic production, physiological buffering and renal excretion of acid equivalents. (Adapted from Remer, 2000.)

Table 1. Protein and sulphur amino acid contents $(\mathrm{g} / \mathrm{kg})$ of a selectowrrcommonly-eaten foods (from Paul et al. 1980; Holland et al. 1991)

\begin{tabular}{|c|c|c|c|}
\hline Food $^{*}$ & Protein & Methionine & Cysteine \\
\hline Hard and soft cheeses & 255 & $6-10$ & $2-3 \cdot 5$ \\
\hline Lean beef steak & 282 & $7 \cdot 4$ & 3.5 \\
\hline White fish (cod) & 186 & $6 \cdot 2$ & $2 \cdot 4$ \\
\hline Oily fish (salmon) & 168 & $5 \cdot 8$ & $2 \cdot 4$ \\
\hline Chicken breast & 320 & $5 \cdot 2$ & $2 \cdot 8$ \\
\hline Peanuts & 245 & $3 \cdot 2$ & $3 \cdot 6$ \\
\hline Boiled egg & 125 & $3 \cdot 9$ & $2 \cdot 2$ \\
\hline Wheat breakfast cereal & 107 & $2 \cdot 0$ & $3 \cdot 0$ \\
\hline Wholemeal bread & 92 & $1 \cdot 5$ & $2 \cdot 4$ \\
\hline White bread & 84 & $1 \cdot 4$ & $2 \cdot 2$ \\
\hline Fresh milk & 32 & 0.94 & $0 \cdot 31$ \\
\hline Boiled spaghetti & 36 & $0 \cdot 74$ & $1 \cdot 2$ \\
\hline Boiled rice & 26 & 0.48 & $0 \cdot 37$ \\
\hline Peas & 67 & $0 \cdot 48$ & 0.56 \\
\hline Potatoes & 18 & 0.23 & $0 \cdot 18$ \\
\hline Onions & 23 & $0 \cdot 20$ & $\dagger$ \\
\hline Oranges & 11 & $0 \cdot 12$ & $0 \cdot 10$ \\
\hline Carrots & 6 & 0.07 & 0.07 \\
\hline Apples & 4 & 0.02 & 0.03 \\
\hline
\end{tabular}

*All values are for cooked foods.

†Negligible amount.

acid-alkali balance has been quantified in different ways, including animal:vegetable protein (Frassetto et al. 2000; Sellmeyer et al. 2001), protein:K (Frassetto et al. 1998) and the potential renal acid load (Remer \& Manz, 1995). When dietary alkali is insufficient there are several acute physiological response mechanisms, including the release of $\mathrm{Na}$, carbonate and citrate from the hydration shell of bone and stimulation of bone resorption (Barzel, 1995; Barzel \& Massey, 1998; Bushinsky et al. 2001). At the renal level
(Fig. 1) the production of $\mathrm{NH}_{3}$ by the proximal tubular cells is an important defence mechanism against acid load, as it combines with $\mathrm{H}^{+}$to form $\mathrm{NH}_{4}{ }^{+}$. This cation then combines with sulphate to form $\left(\mathrm{NH}_{4}\right)_{2} \mathrm{SO}_{4}$, which is excreted in urine, thus leading to the elimination of both ions (Remer, 2000).

Several other mechanisms by which a higher protein intake increases urinary $\mathrm{Ca}$ excretion have been postulated, including increased glomerular filtration rate and reduced tubular reabsorption of $\mathrm{Ca}$. Glomerular filtration rate was increased by approximately $10 \%$ and fractional $\mathrm{Ca}$ reabsorption was decreased by $1 \%$ when six healthy adult males consumed $142 v .47 \mathrm{~g}$ purified protein/d for $10 \mathrm{~d}(\mathrm{Kim}$ \& Linkswiler, 1979). On the basis that approximately $10 \mathrm{~g}$ $\mathrm{Ca} / \mathrm{d}$ are filtered by the glomeruli, it was estimated that the increase in glomerular filtration rate might increase the filtered Ca load by $1 \mathrm{~g} / \mathrm{d}$ and urinary Ca losses by $110 \mathrm{mg} / \mathrm{d}$. Allen et al. (1979) suggested that the decrease in tubular reabsorption of $\mathrm{Ca}$ may be attributed to saturation of the renal transport process for $\mathrm{Ca}$. Other researchers have suggested that reabsorption of $\mathrm{Ca}$ may be reduced when $\mathrm{Ca}$ is complexed to citrate, phosphate, sulphate, bicarbonate or ammonium ions (Lemann et al. 1966; Kim \& Linkswiler, 1979). However, $>20$ years after these theories were put forward there is still no definitive evidence for the mechanisms by which a higher protein intake might impair renal $\mathrm{Ca}$ transport. Furthermore, it is likely that the extent of impairment is dependent on the age and hormonal status of an individual.

\section{Evidence from short-term intervention studies}

Numerous short-term intervention studies have investigated the effects of increased protein intake on $\mathrm{Ca}$ excretion, and details of a number of these studies are outlined in Table 2. On the basis of these and other studies it has been estimated that there is a $1 \mathrm{mg}$ rise in urinary $\mathrm{Ca}$ for each $1 \mathrm{~g}$ rise in dietary protein (Kerstetter \& Allen, 1990). This empirical formula cannot be applied to all protein sources because many of the intervention studies utilised purified protein, including lactalbumin, wheat gluten and casein. The effects of meat protein have been found to be less exaggerated, which may be related to its higher P content (Hegsted et al. 1981; Heaney, 1993). Hegsted et al. (1981) showed that simultaneous increases in protein (from $50 \mathrm{~g}$ to $150 \mathrm{~g}$ ) and $\mathrm{P}$ (from $1010 \mathrm{mg}$ to $2525 \mathrm{mg}$ ) intakes caused a $28 \%$ increase in urinary $\mathrm{Ca}$, whereas an increase in protein intake alone caused a $115 \%$ increase in urinary $\mathrm{Ca}$. One of the mostwidely quoted studies on the effects of meat intake on $\mathrm{Ca}$ excretion and balance (Spencer et al. 1978) showed, in a series of twenty-six studies of fourteen male patients over periods of $16-72 \mathrm{~d}$, that increasing meat intake from an average of $200 \mathrm{~g}$ (approximately $83 \mathrm{~g}$ protein)/d to $300 \mathrm{~g}$ (approximately $140 \mathrm{~g}$ protein)/d did not increase urinary Ca excretion or modify intestinal $\mathrm{Ca}$ absorption (determined using ${ }^{47} \mathrm{Ca}$ ). However, a criticism of this study is that the subjects had a variety of disorders, including hypothyroidism, psychoneurosis, osteoporosis, hypercalciuria and obesity, and so the findings cannot be generalised to the population. Draper et al. (1991) studied the effect of increasing the protein intake of postmenopausal women ( $n$ 8) from $58 \mathrm{~g} / \mathrm{d}$ to $92 \mathrm{~g} / \mathrm{d}$ for $15 \mathrm{~d}$ at each protein level. In 


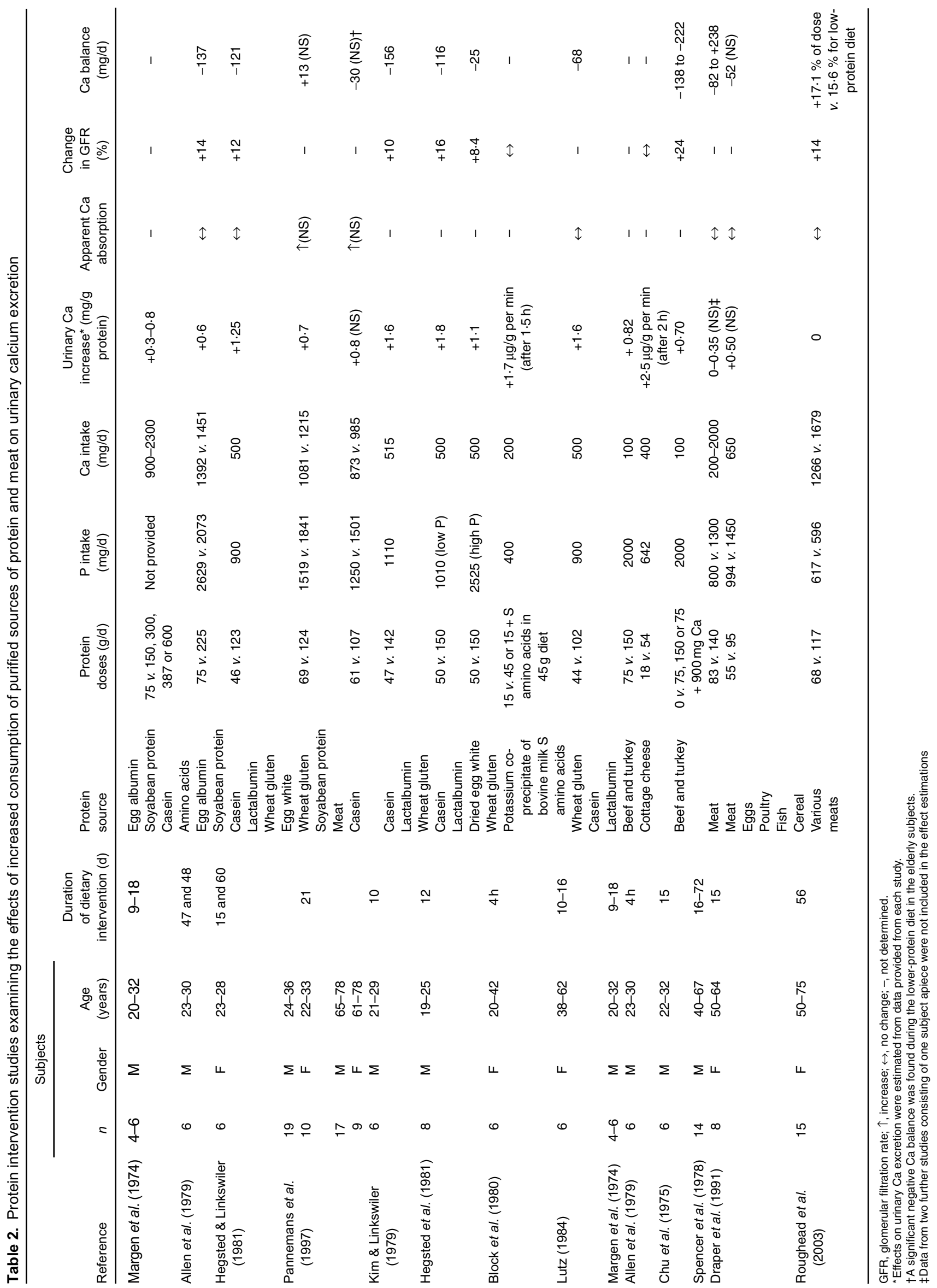


contrast to earlier studies a range of commonly-eaten highprotein foods (high-protein cereal, wholewheat bread, meat, eggs, protein, fish) was used to increase the protein content of the diet. The higher-protein diet did not have a significant effect on urinary $\mathrm{Ca}$ excretion or $\mathrm{Ca}$ balance and there was no change in serum parathyroid hormone. However, urinary cAMP was higher (indicating increased parathyroid hormone activity at the renal level), which led the authors to conclude that the $46 \%$ increase in $\mathrm{P}$ intake on the highprotein diet may have stimulated parathyroid hormone renal reabsorption of $\mathrm{Ca}$, thus partially offsetting the calciuric effects of the higher-protein diet.

There are several difficulties in the interpretation of many of the protein intervention studies, including small numbers of subjects, short duration and wide variations in $\mathrm{Ca}$ and $\mathrm{Na}$ intake. The necessity of having complete faecal and urine collections for calculation of apparent $\mathrm{Ca}$ absorption and $\mathrm{Ca}$ balance can result in calculation errors. In addition, the use of creatinine for estimating glomerular filtration rate has limitations when the meat intake is increased, since meat contains a high level of creatine, which is readily converted to creatinine (Chu et al. 1975).

In the most-recently published study, in which postmenopausal women consumed either low- or high-meat diets (45 g v. $297 \mathrm{~g}$, equivalent to $68 v .117 \mathrm{~g}$ protein/d) for 8 weeks in a controlled crossover design, the high-meat diet was found to have no effect on bone and $\mathrm{Ca}$ metabolism markers, $\mathrm{Ca}$ retention or $\mathrm{Ca}$ absorption (Roughead et al. 2003). Urinary titratable acidity and $\mathrm{pH}$ were initially lower on the high-meat diet, but by 8 weeks the levels of both indicators were similar to those observed for the lowprotein diet, suggesting that adaptation may have occurred. Although glomerular filtration rate was increased by approximately $14 \%$ on the high-meat diet, the authors concluded that this difference was most likely to be a result of the higher creatine intake from meat. At 8 weeks, this study is the longest investigation of the effects of increased meat intake on $\mathrm{Ca}$ retention and other relevant bone measurements, and the findings suggest that adaptation may occur. It is therefore questionable whether the current estimations of the calciuric effects of protein are appropriate, particularly in the absence of estimates of the effects of protein in a broader age-range of subjects from different ethnic groups.

\section{The protein and hip fracture controversy}

The calciuric effect of dietary protein was also believed to provide the mechanistic basis for the association found between cross-cultural hip fracture incidence in women $>50$ years of age and animal-protein intake (Abelow et al. 1992). The highest rate of hip fracture was found to occur in industrialised Western countries, which had animal-protein intakes per capita between 60 and $80 \mathrm{~g} / \mathrm{d}$. On the other hand, the lowest incidence occurred in indigenous Asian and African populations in which animal-protein intakes were considerably lower. Frasetto et al. (2000) extended the same cross-cultural analysis to thirty-three countries and reached a similar conclusion, with the additional finding that hip fracture incidence was inversely related to vegetable-protein intake. There are several obvious limitations to both studies, not least the poor applicability of population food consumption data to women $>50$ years of age. Furthermore, Asian and African ethnic groups are recognised to have a reduced risk of osteoporotic fracture (Aspray et al. 1996; Yan et al. 1999), which may be attributable to a multiplicity of factors, including differences in bone structure, genotype and lifestyle. Frassetto et al. (2000) attempted to overcome this factor by limiting the analysis to predominantly Caucasian populations, and the positive association between hip fracture rate and animal-protein intake remained.

Whether vegetarians have a skeletal advantage in terms of better bone mineral status or reduced fracture incidence has not been established (Department of Health, 1998). Higher consumption of cereal grains and nuts could potentially provide a similar dietary acid load to that of animal protein (Table 1). However, this effect may be counteracted by higher consumption of alkali foods. Most of the studies examining differences between vegetarians and non-vegetarians have been conducted in very specific population groups (Marsh et al. 1980, 1983, 1988; Tylavsky \& Anderson, 1988), which does not permit generalisation to the wider population.

\section{Prospective evidence for a negative effect of protein on bone health}

There are two prospective studies providing evidence that fracture incidence is related to higher protein intake (Feskanich et al. 1996; Meyer et al. 1997). The Nurse's Health Study (Feskanich et al. 1996) was a 12-year survey of 85900 women aged 35-59 years. Protein intake was assessed by a mailed food-frequency questionnaire at three time-points (baseline, year 4 and year 6) and fracture incidence was self-reported biennially. Women who consumed $>95 \mathrm{~g}$ total protein (i.e. animal and vegetable protein)/d had a greater risk of forearm fracture compared with those who consumed $<68 \mathrm{~g} / \mathrm{d}$. A higher intake of vegetable protein alone was not associated with increased risk, but women consuming five or more servings of beef, pork or lamb had an increased risk of forearm fracture compared with women who consumed less than one serving per week. Meyer et al. (1997) found no association between non-dairy animalprotein intake and hip fracture incidence in a prospective study of 40000 Norwegian men and women (aged 35-49 years at baseline) conducted over an average period of 11 (range 0.01-13.8) years. At one time point during the study subjects completed a food-frequency questionnaire, which they filled in at home and returned by post. Intake of nondairy animal protein was not found to be associated with hip fracture, but women in the lowest quartile of $\mathrm{Ca}$ intake and highest quartile of non-dairy animal-protein intake (values not provided) had an elevated risk of fracture. This pattern was not observed with total protein intake. A major limitation of both studies was the use of a mailed foodfrequency questionnaire on a limited number of occasions and limited evaluation of other lifestyle and dietary factors that may have contributed to fracture risk. 


\section{Effects of protein intake on calcium recommendations for developing countries}

Although the impact of protein intake on Ca requirements and bone health has not been established conclusively, the recently revised dietary $\mathrm{Ca}$ recommendations for developing countries (Food and Agriculture Organization/World Health Organization Expert Consultation, 2002) accounted for the lower protein intake $(20-40 \mathrm{~g} / \mathrm{d})$ of developing countries in their estimations of theoretical $\mathrm{Ca}$ requirements. By using the estimated $1 \mathrm{mg}$ increment in Ca for every $1 \mathrm{~g}$ protein intake, the recommendation for adults was calculated to be $750 \mathrm{mg} / \mathrm{d}$, as compared with the $1000 \mathrm{mg} / \mathrm{d}$ recommendation that was based on Western European, American and Canadian data. Although this downward adjustment attempts to account for ethnic differences in $\mathrm{Ca}$ requirements, it is not known whether a higher protein intake results in calciuria in non-Caucasian individuals. As with the cross-cultural associations found between protein intake and hip fracture, there are likely to be numerous other factors that influence bone health and $\mathrm{Ca}$ requirements in developing countries.

\section{Protein supplementation and reduced bone loss}

In parallel with the controversy that grew over the negative effects of protein on bone health, there were also studies that suggested that certain segments of the population could benefit from increasing their protein intake. Geinoz et al. (1993) observed that patients with higher protein intakes during their hospital stay had higher femoral neck and lumbar spine bone mineral densities (BMD). After 4 weeks in hospital women with a higher protein intake had better muscle strength and stair-climbing performance. Such findings do not suggest a specific effect of protein intake per se, but may reflect better general health status and thus better appetite in these patients. However, two further studies substantiated the observational evidence by demonstrating that protein supplementation for 5 weeks reduced the medical complication rate and duration of hip fracture in patients with a recent hip fracture (Delmi et al. 1990; Tkatch et al. 1992). Further convincing evidence of the benefits of protein supplementation in this age-group was provided by Schurch et al. (1998) in a randomised double-blind protein supplementation trial with elderly Swiss patients with hip fracture (thirty-seven women and four men, aged 81.1 (SD 7.4) years) who had a baseline protein intake of $45.0(\mathrm{SD} 15.2) \mathrm{g} / \mathrm{d}$. All patients received one oral dose of cholecalciferol $(5 \mathrm{mg})$ to correct any possible vitamin $\mathrm{D}$ deficiency and were randomised to receive either a protein supplement (containing $900 \mathrm{~g}$ milk proteins $/ \mathrm{kg}$ and providing (/d) $300 \mu \mathrm{g}$ vitamin A, $30 \mu \mathrm{g}$ vitamin K, $20 \mathrm{mg}$ vitamin C, $550 \mathrm{mg} \mathrm{Ca}, 91 \mathrm{mg} \mathrm{Mg}$, $429 \mathrm{mg}$ $\mathrm{P})$ or an isoenergetic placebo containing maltodextrins, but not the multinutrients. After 6 months of supplementation the protein-supplemented group were found to have higher levels of insulin like-growth factor 1 (IGF-1) and reduced proximal femur bone loss compared with the placebo group. Hospital stay was also reduced by $21 \mathrm{~d}$ in the proteinsupplemented group. Much emphasis has been placed on the independent effects of protein in this study, but it is also possible that they may be a result of the combined or additive effects of protein and the various nutrients contained in the supplement. No other intervention studies have been conducted in this age-group and there is an immediate need for longer-term studies to determine whether increasing protein intake would be an effective means of reducing fracture-related morbidity and maintaining bone health in elderly men and women. Identification of the upper intake limit and interactions with other nutrients in relation to bone is also essential.

\section{Bone loss is reduced in elderly men and women with high animal-protein intake}

Two large prospective studies have shown that higher animal-protein intake is associated with reduced bone loss over a 4-year period in elderly men and women who were participants of the Framingham Osteoporosis Cohort (Hannan et al. 2000) and The Rancho Bernardo Heart and Chronic Disease Study (Promislow et al. 2002). In a third study of elderly women from the Iowa Women's Health Study (Munger et al. 1999) those who had the highest animal-protein intake had a decreased risk of hip fracture. In the Framingham cohort the mean total protein intake for the men $(n$ 224) was 69.3 (SD 23.9) g/d and that for the women (n 392) was 68.0 (SD 23.5) g/d. After adjustment for all potential confounders, including age, height, weight and weight changes, total energy intake, smoking, physical activity, those in the lowest quartile of percentage protein intake showed the greatest BMD losses at the femur and spine sites and lower percentage animal protein was related to greater bone loss at the femur and spine. There were similar findings in Rancho Bernardo Study (Promislow et al. 2002), with a high animal-protein intake also appearing to have a protective effect against bone loss. It was surprising, however, that the greatest bone losses occurred in women with the highest vegetable-protein intake and a similar non-significant trend was found in men. The Iowa Women's Health Study (Munger et al. 1999) also reported an increase in age-adjusted hip fracture risk with increasing quartile of vegetable-protein consumption. This finding is in conflict with the evidence that higher fruit and vegetable intake has a positive effect on bone (New et al. 1997, 2000; Muhlbauer \& Li, 1999; Tucker et al. 1999). It is difficult to explain the greater bone loss with the higher-vegetableprotein diet, because the components of the diet were not described in either study, nor were the associated lifestyle factors discussed, although animal-protein intake was shown to be positively associated with vegetable-protein intake in the Rancho Bernardo Study. Further research is needed in order to elucidate the interactions between animal and vegetable protein and their relative importance for maintaining bone health in the elderly.

\section{Mechanisms by which protein positively affects bone health}

Albright et al. (1941) wrote: 'a diet inadequate in protein might lead to a negative nitrogen balance and this in turn might make it impossible for the osteoblasts to lay down the necessary organic matrix, which is the first step in the 
formation of bone. We believe that some of the osteopathies which have been attributed to a lack of calcium and phosphorus in the diet are really due to protein starvation.' Since this statement was made, the understanding of the mechanisms of action of dietary protein has expanded to encompass a regulatory role in growth hormone and IGF-1 metabolism.

IGF-1 is an essential mediator of tissue anabolism, stimulating growth of multiple cell types, transport of amino acids and protein synthesis in muscle and skeletal tissues (Clemmons \& Underwood, 1991). During growth it stimulates proliferation and differentiation of chondrocytes in the epiphyseal plate (Wang et al. 1999) and it is thus an essential factor for longitudinal growth. IGF-1 has been shown in vitro to increase osteoblast activity (Mohan et al. 1992; Langdahl et al. 1998) and production of type I collagen (McCarthy et al. 1989) and to act as a coupling factor for bone resorption and bone formation (Rubin et al. 2002). IGF-1 also has an important role in the regulation of $\mathrm{Ca}$ and $\mathrm{P}$ metabolism by stimulating renal transport of inorganic phosphate and kidney production of 1,25dihydroxycholecalciferol (Caverzasio \& Bonjour, 1989). This function may be of paramount importance during growth, when the high rate of collagen synthesis and mineralisation results in high requirements for $\mathrm{Ca}$ and phosphate. More recently, it has been shown that selective knock-out of the IGF-1 receptor gene in mouse osteoblasts results in mice with normal bone size and weight but a decrease in the rate of mineralisation of osteoid (Zhang et al. 2002). The authors suggested that osteoblast-derived IGF-1 might be essential for coupling collagen synthesis to sustained mineralisation.

\section{Regulation of insulin-like growth factor 1 production by dietary protein}

Given its essential role in growth and protein synthesis it is not surprising that hepatic IGF-1 production, plasma IGF-1 concentration and the proportion of free or active IGF-1 (i.e. the portion not bound to its principal binding protein IGFbinding protein 3) is regulated by dietary protein intake (Clemmons \& Underwood, 1991; Thissen et al. 1994; Fig. 2). In animal studies protein fasting has been shown to induce a decrease in hepatic growth hormone-binding sites (Maiter et al. 1989) and protein restriction results in growth hormone-receptor defects (Thissen et al. 1992). The consequences of this effect include decreased hepatic production of IGF-1 and a lowering of the circulating concentration. Elevated production of IGF-binding protein 3 exacerbates the effect by decreasing the proportion of free IGF-1, thus decreasing its anabolic capacity (Clemmons \& Underwood, 1991) and increasing IGF-1 clearance (Thissen et al. 1992). In protein-restricted rats normalisation of plasma IGF-1 by infusion failed to promote growth (Thissen et al. 1991), indicating that in the absence of an adequate protein supply end-organ resistance occurs. Several animal studies have shown that the IGF-1 deficit caused by protein restriction has adverse consequences for bone, including osteoporosis, impaired cortical bone formation and osteoblast resistance (Bourrin et al. 2000a,b).

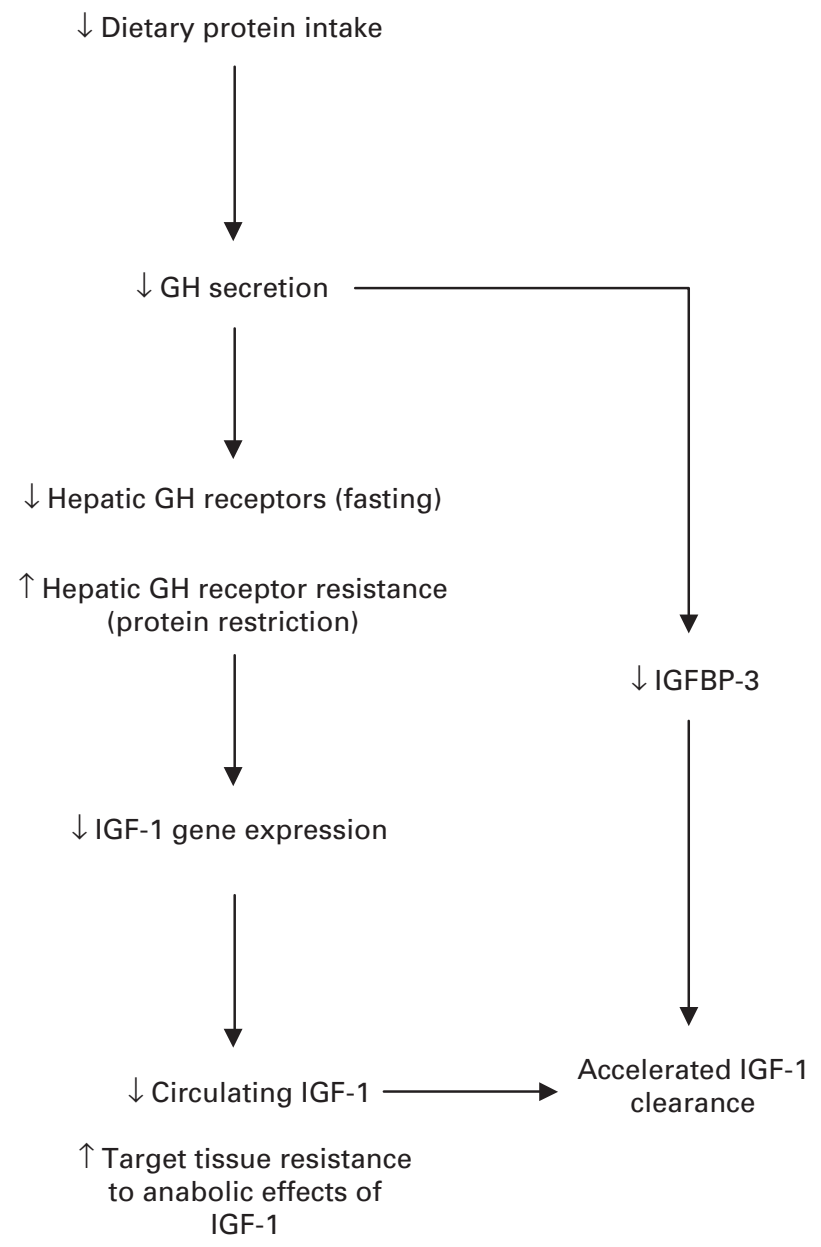

Fig. 2. The effects of protein on insulin-like growth factor (IGF) production and plasma concentration. GH, growth hormone; IGFBP, IGF-binding protein; $\downarrow$, decreased; $\uparrow$, increased. (Adapted from Thissen et al. 1994.)

In human subjects cross-sectional studies in older women have shown a positive association between plasma IGF-1 and BMD (Langlois et al. 1998) and muscle strength and mobility (Cappola et al. 2001). It has also been shown that serum concentrations of IGF-1 and IGF-binding protein 3 are lower in osteoporotic patients with spinal fractures compared with those without fractures (Sugimoto et al. 1997). However, with the exception of the study described earlier by Schurch et al. (1998), which showed that protein supplementation increased the IGF-1 concentration in elderly patients with hip fracture, there are no other human intervention studies that have evaluated the effects of modifying protein intake from different sources on IGF-1 in this age-group. IGF-1 production is also influenced by sex steroid hormone status, and the relative importance of the age-related decline in oestrogen and androgen status compared with the influence of protein intake remains undetermined in man. 


\section{Calcium balance}

Although many of the early studies focused on the negative effects of a high protein intake on $\mathrm{Ca}$ balance, more recent evidence suggests that a low protein intake has a negative effect on $\mathrm{Ca}$ metabolism and balance. Short-term intervention trials in healthy women have shown that a low protein intake $(0.7 \mathrm{~g} / \mathrm{kg})$ is associated with an increase in serum parathyroid hormone and a reduction in both urinary $\mathrm{Ca}$ excretion and $\mathrm{Ca}$ absorption. The latter finding was not anticipated, as it was expected that increased parathyroid hormone would be associated with greater production of 1,25-dihydroxyvitamin $\mathrm{D}$ and increased $\mathrm{Ca}$ absorption (Kerstetter et al. 1997, 2000, 2003). These findings led the authors to suggest that intestinal and/or skeletal handling of $\mathrm{Ca}$ is altered by a low-protein diet. Although the duration of these studies was too short $(4 \mathrm{~d})$ to indicate whether adaptation could occur, it is possible that the negative effects of a low protein intake on bone loss in the elderly (Hannan et al. 2000; Promislow et al. 2002) could be mediated by similar perturbations in $\mathrm{Ca}$ metabolism and absorption. However, this mechanism remains to be proven. It has been suggested that the essential amino acid lysine may play a role in $\mathrm{Ca}$ metabolism. Studies in animals and human subjects have shown that $\mathrm{Ca}$ absorption is higher when lysine intake is increased (Wolinsky \& Fosmire, 1982; Civitelli et al. 1992; Civitelli, 1993), but the underlying mechanism has not been identified.

\section{Protein-calcium interaction}

In recent years there has been a focus on the possible interaction between dietary $\mathrm{Ca}$ and protein intake. Although the possible negative effects of a higher protein intake may be compensated by a high $\mathrm{Ca}$ intake or exacerbated by a low $\mathrm{Ca}$ intake, the potential anabolic effects of protein may be maximised by a higher $\mathrm{Ca}$ intake. Evidence in favour of the former theory has been suggested in the Nurse's Health Study (Feskanich et al. 1996), which found that women with a high-total-protein (>95 g/d) high-Ca diet (>827 mg/d) had a lower risk of fracture than women with a high-total-protein low-Ca diet $(<531 \mathrm{mg} / \mathrm{d})$. Limited evidence is also available from the study by Meyer et al. (1997), which showed that women with a low $\mathrm{Ca}$ and high non-dairy animal-protein intake had a greater risk of fracture.

Dawson-Hughes \& Harris (2002) showed that Casupplemented older men and women ( $\geq 65$ years of age) in the highest tertile of protein intake (as \% energy) had the greatest increases in whole-body and femoral neck BMD compared with those in the lowest tertile. No association was found between protein intake and bone change in the placebo group. Most recently, Rapuri et al. (2003) examined the effects of protein intake (also as \% energy) on baseline BMD and rate of subsequent bone loss in 65-77-year old women. The highest quartile of protein intake was associated with higher BMD at the spine, mid radius and whole body. Among women in the lowest quartile of $\mathrm{Ca}$ intake $(<480 \mathrm{mg} / \mathrm{d})$ no significant association was found between spine BMD and protein intake. However, in the upper two quartiles of $\mathrm{Ca}$ intake an association was observed between spine BMD and protein intake. A similar association was also seen at the whole body level. Longitudinally, bone loss did not differ by quartile of protein intake and $\mathrm{Ca}$ intake showed no effect. A point worth noting from this study was that dietary vitamin D increased with increasing protein intake, suggesting that the benefits of a higher protein intake may also be explained by other factors.

For the purposes of the present review a preliminary analysis of our own data from the Cambridge Bone Studies was carried out to examine whether there was an interaction between $\mathrm{Ca}$ supplementation and baseline protein intake in 16-18-year-old boys ( $n$ 110) and girls ( $n$ 101) who participated in two separate $\mathrm{Ca}$ intervention studies (Prentice et al. 2002; Stear et al. 2003). In these studies $\mathrm{Ca}$ supplementation (1000 mg $\mathrm{Ca}$ as $\mathrm{CaCO}_{3} / \mathrm{d}$ ) increased bone mineral content of the whole body, hip and spine in boys supplemented for 12.7 (SD 0.5) months. Similar results were observed in girls with higher compliance supplemented for 15.5 (SD 0.7) months. No significant interaction was found between baseline dietary protein intake (as \% energy) and $\mathrm{Ca}$ supplementation in relation to bone mineral content change in either the boys or the girls, and there was no significant effect of protein intake on bone changes in the placebo group (F Ginty and A Prentice, unpublished results). However, as with the studies described earlier, the interpretation is limited by the post hoc nature of the analysis. It is necessary to conduct studies that specifically set out to address the mechanistic basis for an interaction between protein and $\mathrm{Ca}$ in different agegroups.

\section{Effects of protein on peak bone mass}

Although an adequate intake of protein is essential for growth, it is not known whether variations in protein intake and quality contribute to variations in bone size, mineral content and ultimately the achievement of optimal peak bone mass. Studies have shown a positive association between protein intake and bone mineral status in children (Hoppe et al. 2000), adolescents (Rizzoli, 1998) and young women aged 18-31 years (Teegarden et al. 1998). However, the findings in the younger subjects do not necessarily indicate a causal relationship, since protein intake is likely to be driven by growth requirements. Furthermore, BMD is not independent of size, and such associations may be artefacts (Prentice et al. 1994). Cadogan et al. (1998) found that supplementation of 12-year-old girls with $568 \mathrm{ml}$ (1 pint) milk daily for 18 months was associated with an increase in plasma IGF-1 and bone mineral status compared with control subjects. It was proposed that the higher protein content of milk mediated a rise in plasma IGF-1 that, in turn, may have had a stimulatory affect on osteoblast activity, or may have promoted bone mineralisation, as suggested recently by Zhang et al. (2002). Bone growth is site-specific and varies with the stage of puberty, and it has been hypothesised that disruptions to growth through illness, poor diet etc. may result in site-specific deficits in bone mineral status and quality (Bass et al. 1999; Seeman et al. 2000). IGF-1 is a major determinant of bone growth and mineral content (Yakar et al. 2002), and plasma concentrations are 
approximately four to five times higher in adolescents than in adult (Juul et al. 1994). However, there are no data on the extent to which IGF-1 production is regulated by protein intake during puberty and whether variations in IGF-1 as a result of lower protein intake result in site-specific deficits, thus increasing risk of fragility later in life.

\section{Summary and conclusions}

Although there is much supporting evidence and a mechanistic basis for the calciuric effects of a high protein intake, there is a lack of evidence from long-term studies in different age-groups of continued urinary $\mathrm{Ca}$ losses and bone loss. Further information is required on the compensatory effects of a Ca- and/or alkali-rich diet. It is important in terms of public health to determine whether a low protein intake in the elderly predisposes them to a greater rate of bone loss. It is also necessary to identify the protective aspects of a higher-protein diet and whether there are other underlying dietary or lifestyle characteristics that may also explain the lower rate of bone loss observed in prospective studies. The finding that protein, multimineral and vitamin supplementation of elderly patients with hip fracture increases recovery time and reduces bone loss is also important. However, more studies are needed to support these findings and to determine whether it is an effect of protein per se, or a multi-nutrient effect. Although there is no doubt that an adequate protein intake during childhood and adolescence is essential to support normal growth and skeletal development, more research is needed to evaluate the role of protein quality and protein-diet interactions in the achievement of optimal peak bone mass. The available evidence appears to suggest that protein may have a biphasic effect on bone health. However, the upper and lower thresholds are difficult to define without taking overall diet, health status and age into account.

\section{References}

Abelow BJ, Holford TR \& Insogna KL (1992) Cross-cultural association between dietary animal protein and hip fracture: a hypothesis. Calcified Tissue International 50, 14-18.

Albright F, Smith PH \& Richardson AM (1941) Postmenopausal osteoporosis. Journal of the American Medical Association 116, 2465-2474.

Allen LH, Oddoye EA \& Margen S (1979) Protein-induced hypercalciuria: a longer term study. American Journal of Clinical Nutrition 32, 741-749.

Aspray TJ, Prentice A, Cole TJ, Sawo Y, Reeve J \& Francis RM (1996) Low bone mineral content is common but osteoporotic fractures are rare in elderly rural Gambian women. Journal of Bone and Mineral Research 11, 1019-1025.

Barzel US (1995) The skeleton as an ion exchange system: implications for the role of acid-base imbalance in the genesis of osteoporosis. Journal of Bone and Mineral Research 10, $1431-1436$.

Barzel US \& Massey LK (1998) Excess dietary protein can adversely affect bone. Journal of Nutrition 128, 1051-1053.

Bass S, Delmas PD, Pearce G, Hendrich E, Tabensky A \& Seeman E (1999) The differing tempo of growth in bone size, mass, and density in girls is region-specific. Journal of Clinical Investigation 104, 795-804.
Block GD, Wood RJ \& Allen LH (1980) A comparison of the effects of feeding sulfur amino acids and protein on urine calcium in man. American Journal of Clinical Nutrition 33, 2128-2136.

Bourrin S, Ammann P, Bonjour JP \& Rizzoli R (2000a) Dietary protein restriction lowers plasma insulin-like growth factor I (IGF-I), impairs cortical bone formation, and induces osteoblastic resistance to IGF-I in adult female rats. Endocrinology 141, 3149-3155.

Bourrin S, Toromanoff A, Ammann P, Bonjour JP \& Rizzoli R (2000b) Dietary protein deficiency induces osteoporosis in aged male rats. Journal of Bone and Mineral Research 15, 1555-1563.

Buclin T, Cosma M, Appenzeller M, Jacquet AF, Decosterd LA, Biollaz J \& Burckhardt P (2001) Diet acids and alkalis influence calcium retention in bone. Osteoporosis International 12, 493-499.

Bushinsky DA, Parker WR, Alexander KM \& Krieger NS (2001) Metabolic, but not respiratory, acidosis increases bone PGE(2) levels and calcium release. American Journal of Physiology 281, F1058-F1066.

Cadogan J, Blumsohn A, Barker ME \& Eastell R (1998) A longitudinal study of bone gain in pubertal girls: anthropometric and biochemical correlates. Journal of Bone and Mineral Research 13, 1602-1612.

Cappola AR, Bandeen-Roche K, Wand GS, Volpato S \& Fried LP (2001) Association of IGF-I levels with muscle strength and mobility in older women. Journal of Clinical Endocrinology and Metabolism 86, 4139-4146.

Caverzasio J \& Bonjour JP (1989) Insulin-like growth factor I stimulates Na-dependent Pi transport in cultured kidney cells. American Journal of Physiology 257, F712-F717.

Chu JY, Margen S \& Costa FM (1975) Studies in calcium metabolism. II. Effects of low calcium and variable protein intake on human calcium metabolism. American Journal of Clinical Nutrition 28, 1028-1035.

Civitelli R (1993) Dietary L-lysine and calcium metabolism in humans: background. Nutrition 9, 299-300.

Civitelli R, Villareal DT, Agnusdei D, Nardi P, Avioli LV \& Gennari C (1992) Dietary L-lysine and calcium metabolism in humans. Nutrition 8, 400-405.

Clemmons DR \& Underwood LE (1991) Nutritional regulation of IGF-I and IGF binding proteins. Annual Review of Nutrition 11, 393-412.

Dawson-Hughes B \& Harris SS (2002) Calcium intake influences the association of protein intake with rates of bone loss in elderly men and women. American Journal of Clinical Nutrition $\mathbf{7 5}$, 773-779.

Delmi M, Rapin CH, Bengoa JM, Delmas PD, Vasey H \& Bonjour JP (1990) Dietary supplementation in elderly patients with fractured neck of the femur. Lancet 335, 1013-1016.

Department of Health (1998) Nutrition and Bone Health with Particular Reference to Calcium and Vitamin D. Report on Health and Social Subjects no. 49. London: The Stationery Office.

Draper HH, Piche LA \& Gibson RS (1991) Effects of a high protein intake from common foods on calcium metabolism in a cohort of postmenopausal women. Nutrition Research 11, 273-281.

Feskanich D, Willett WC, Stampfer MJ \& Colditz GA (1996) Protein consumption and bone fractures in women. American Journal of Epidemiology 143, 472-479.

Food and Agriculture Organization/World Health Organization Expert Consultation (2002) Human Vitamin and Mineral Requirements, pp. 151-179. Rome: FAO.

Frassetto LA, Todd KM, Morris RC Jr \& Sebastian A (1998) Estimation of net endogenous noncarbonic acid production in humans from diet potassium and protein contents. American Journal of Clinical Nutrition 68, 576-583.

Frassetto LA, Todd KM, Morris RC Jr \& Sebastian A (2000) Worldwide incidence of hip fracture in elderly women: relation 
to consumption of animal and vegetable foods. Journal of Gerontology 55A, M585-M592.

Geinoz G, Rapin CH, Rizzoli R, Kraemer R, Buchs B, Slosman D, Michel JP \& Bonjour JP (1993) Relationship between bone mineral density and dietary intakes in the elderly. Osteoporosis International 3, 242-248.

Hannan MT, Tucker KL, Dawson-Hughes B, Cupples LA, Felson DT \& Kiel DP (2000) Effect of dietary protein on bone loss in elderly men and women: the Framingham Osteoporosis Study. Journal of Bone and Mineral Research 15, 2504-2512.

Heaney RP (1993) Protein intake and the calcium economy. Journal of the American Dietetic Association 93, 1259-1260.

Hegsted M \& Linkswiler HM (1981) Long-term effects of level of protein intake on calcium metabolism in young adult women. Journal of Nutrition 111, 244-251.

Hegsted M, Schuette SA, Zemel MB \& Linkswiler HM (1981) Urinary calcium and calcium balance in young men as affected by level of protein and phosphorus intake. Journal of Nutrition 111, 553-562.

Holland B, Welch A, Unwin I, Buss D, Paul A \& Southgate D (1991) McCance and Widdowson's The Composition of Food. Cambridge: Royal Society of Chemistry.

Hoppe C, Molgaard C \& Michaelsen KF (2000) Bone size and bone mass in 10-year-old Danish children: effect of current diet. Osteoporosis International 11, 1024-1030.

Juul A, Bang P, Hertel NT, Main K, Dalgaard P, Jorgensen K, Muller J, Hall K \& Skakkebaek NE (1994) Serum insulin-like growth factor-I in 1030 healthy children, adolescents, and adults: relation to age, sex, stage of puberty, testicular size, and body mass index. Journal of Clinical Endocrinology and Metabolism 78, 744-752.

Kerstetter JE \& Allen LH (1990) Dietary protein increases urinary calcium. Journal of Nutrition 120, 134-136.

Kerstetter JE, Caseria DM, Mitnick ME, Ellison AF, Gay LF, Liskov TA, Carpenter TO \& Insogna KL (1997) Increased circulating concentrations of parathyroid hormone in healthy, young women consuming a protein-restricted diet. American Journal of Clinical Nutrition 66, 1188-1196.

Kerstetter JE, O'Brien KO \& Insogna KL (2003) Low protein intake: the impact on calcium and bone homeostasis in humans. Journal of Nutrition 133, 855S-861S.

Kerstetter JE, Svastisalee CM, Caseria DM, Mitnick ME \& Insogna KL (2000) A threshold for low-protein-diet-induced elevations in parathyroid hormone. American Journal of Clinical Nutrition 72, 168-173.

Kim Y \& Linkswiler HM (1979) Effect of level of protein intake on calcium metabolism and on parathyroid and renal function in the adult human male. Journal of Nutrition 109, 1399-1404.

Langdahl BL, Kassem M, Moller MK \& Eriksen EF (1998) The effects of IGF-I and IGF-II on proliferation and differentiation of human osteoblasts and interactions with growth hormone. European Journal of Clinical Investigation 28, 176-183.

Langlois JA, Rosen CJ, Visser M, Hannan MT, Harris T, Wilson PW \& Kiel DP (1998) Association between insulin-like growth factor I and bone mineral density in older women and men: the Framingham Heart Study. Journal of Clinical Endocrinology and Metabolism 83, 4257-4262.

Lemann J Jr, Litzow JR \& Lennon EJ (1966) The effects of chronic acid loads in normal man: further evidence for the participation of bone mineral in the defense against chronic metabolic acidosis. Journal of Clinical Investigation 45, 1608-1614.

Lutz J (1984) Calcium balance and acid-base status of women as affected by increased protein intake and by sodium bicarbonate ingestion. American Journal of Clinical Nutrition 39, 281-288.

McCarthy TL, Centrella M \& Canalis E (1989) Insulin-like growth factor (IGF) and bone. Connective Tissue Research 20, $277-282$.
Maiter D, Fliesen T, Underwood LE, Maes M, Gerard G, Davenport ML \& Ketelslegers JM (1989) Dietary protein restriction decreases insulin-like growth factor I independent of insulin and liver growth hormone binding. Endocrinology 124, 2604-2611.

Margen S, Chu JY, Kaufmann NA \& Calloway DH (1974) Studies in calcium metabolism. I. The calciuretic effect of dietary protein. American Journal of Clinical Nutrition 27, 584-589.

Marsh AG, Sanchez TV, Chaffee FL, Mayor GH \& Mickelsen O (1983) Bone mineral mass in adult lacto-ovo-vegetarian and omnivorous males. American Journal of Clinical Nutrition 37, 453-456.

Marsh AG, Sanchez TV, Michelsen O, Chaffee FL \& Fagal SM (1988) Vegetarian lifestyle and bone mineral density. American Journal of Clinical Nutrition 48, 837-841.

Marsh AG, Sanchez TV, Midkelsen O, Keiser J \& Mayor G (1980) Cortical bone density of adult lacto-ovo-vegetarian and omnivorous women. Journal of the American Dietetic Association 76, 148-151.

Meyer HE, Pedersen JI, Loken EB \& Tverdal A (1997) Dietary factors and the incidence of hip fracture in middle-aged Norwegians. A prospective study. American Journal of Epidemiology 145, 117-123.

Mohan S, Strong DD, Lempert UG, Tremollieres F, Wergedal JE \& Baylink DJ (1992) Studies on regulation of insulin-like growth factor binding protein (IGFBP)-3 and IGFBP-4 production in human bone cells. Acta Endocrinologica 127, 555-564.

Muhlbauer RC \& Li F (1999) Effect of vegetables on bone metabolism. Nature 401, 343-344.

Munger RG, Cerhan JR \& Chiu BC (1999) Prospective study of dietary protein intake and risk of hip fracture in postmenopausal women. American Journal of Clinical Nutrition 69, 147-152.

New SA, Bolton-Smith C, Grubb DA \& Reid DM (1997) Nutritional influences on bone mineral density: a cross-sectional study in premenopausal women. American Journal of Clinical Nutrition 65, 1831-1839.

New SA, Robins SP, Campbell MK, Martin JC, Garton MJ, Bolton-Smith C, Grubb DA, Lee SJ \& Reid DM (2000) Dietary influences on bone mass and bone metabolism: further evidence of a positive link between fruit and vegetable consumption and bone health? American Journal of Clinical Nutrition 71, 142-151.

Oh MS (2000) New perspectives on acid-base balance. Seminars in Dialysis 13, 212-219.

Pannemans DL, Schaafsma G \& Westerterp KR (1997) Calcium excretion, apparent calcium absorption and calcium balance in young and elderly subjects: influence of protein intake. British Journal of Nutrition 77, 721-729.

Paul AA, Southgate DAT \& Russell J (1980) First Supplement to McCance and Widdowson's The Composition of Foods. London: H.M. Stationery Office.

Prentice A, Parsons TJ \& Cole TJ (1994) Uncritical use of bone mineral density in absorptiometry may lead to size-related artifacts in the identification of bone mineral determinants. American Journal of Clinical Nutrition 60, 837-842.

Prentice A, Stear SJ, Ginty F, Jones SC, Mills L \& Cole TJ (2002) Calcium supplementation increases height and bone mass of 16-18 year old boys. Journal of Bone and Mineral Research 17, S397.

Promislow JH, Goodman-Gruen D, Slymen DJ \& Barrett-Connor E (2002) Protein consumption and bone mineral density in the elderly: the Rancho Bernardo Study. American Journal of Epidemiology 155, 636-644.

Rapuri PB, Gallagher JC \& Haynatzka V (2003) Protein intake: effects on bone mineral density and the rate of bone loss in elderly women. American Journal of Clinical Nutrition 77, $1517-1525$. 
Remer T (2000) Influence of diet on acid-base balance. Seminars in Dialysis 13, 221-226.

Remer T \& Manz F (1995) Potential renal acid load of foods and its influence on urine pH. Journal of the American Dietetic Association 95, 791-797.

Rizzoli R (1998) Protein intake and osteoporosis. In Nutritional Aspects of Osteoporosis, pp. 141-154 [P Burckhardt, B Dawson-Hughes and RP Heaney, editors]. New York: Springer-Verlag.

Roughead ZK, Johnson LK, Lykken GI \& Hunt JR (2003) Controlled high meat diets do not affect calcium retention or indices of bone status in healthy postmenopausal women. Journal of Nutrition 133, 1020-1026.

Rubin J, Ackert-Bicknell CL, Zhu L, Fan X, Murphy TC, Nanes MS, Marcus R, Holloway L, Beamer WG \& Rosen CJ (2002) IGF-I regulates osteoprotegerin (OPG) and receptor activator of nuclear factor-kappaB ligand in vitro and OPG in vivo. Journal of Clinical Endocrinology and Metabolism 87, 4273-4279.

Schurch MA, Rizzoli R, Slosman D, Vadas L, Vergnaud P \& Bonjour JP (1998) Protein supplements increase serum insulin-like growth factor-I levels and attenuate proximal femur bone loss in patients with recent hip fracture. A randomized, double-blind, placebocontrolled trial. Annals of Internal Medicine 128, 801-809.

Seeman E, Karlsson MK \& Duan Y (2000) On exposure to anorexia nervosa, the temporal variation in axial and appendicular skeletal development predisposes to site-specific deficits in bone size and density: a cross-sectional study. Journal of Bone and Mineral Research 15, 2259-2265.

Sellmeyer DE, Stone KL, Sebastian A \& Cummings SR (2001) A high ratio of dietary animal to vegetable protein increases the rate of bone loss and the risk of fracture in postmenopausal women. Study of Osteoporotic Fractures Research Group. American Journal of Clinical Nutrition 73, 118-122.

Spencer H, Kramer L, Osis D \& Norris C (1978) Effect of a high protein (meat) intake on calcium metabolism in man. American Journal of Clinical Nutrition 31, 2167-2180.

Stear SJ, Prentice A, Jones SC \& Cole TJ (2003) Effect of a calcium and exercise intervention on bone mineral status of 16-18 year old adolescent girls. American Journal of Clinical Nutrition 77, 985-992.

Sugimoto T, Nishiyama K, Kuribayashi F \& Chihara K (1997) Serum levels of insulin-like growth factor (IGF) I, IGF-binding protein (IGFBP)-2, and IGFBP-3 in osteoporotic patients with and without spinal fractures. Journal of Bone and Mineral Research 12, 1272-1279.

Teegarden D, Lyle RM, McCabe GP, McCabe LD, Proulx WR, Michon K, Knight AP, Johnston CC \& Weaver CM (1998)
Dietary calcium, protein, and phosphorus are related to bone mineral density and content in young women. American Journal of Clinical Nutrition 68, 749-754.

Thissen JP, Davenport ML, Pucilowska JB, Miles MV \& Underwood LE (1992) Increased serum clearance and degradation of 125I-labeled IGF-I in protein-restricted rats. American Journal of Physiology 262, E406-E411.

Thissen JP, Ketelslegers JM \& Underwood LE (1994) Nutritional regulation of the insulin-like growth factors. Endocrine Reviews 15, 80-101.

Thissen JP, Underwood LE, Maiter D, Maes M, Clemmons DR \& Ketelslegers JM (1991) Failure of insulin-like growth factor-I (IGF-I) infusion to promote growth in protein-restricted rats despite normalization of serum IGF-I concentrations. Endocrinology 128, 885-890.

Tkatch L, Rapin CH, Rizzoli R, Slosman D, Nydegger V, Vasey H \& Bonjour JP (1992) Benefits of oral protein supplementation in elderly patients with fracture of the proximal femur. Journal of the American College of Nutrition 11, 519-525.

Tucker KL, Hannan MT, Chen H, Cupples LA, Wilson PW \& Kiel DP (1999) Potassium, magnesium, and fruit and vegetable intakes are associated with greater bone mineral density in elderly men and women. American Journal of Clinical Nutrition 69, 727-736.

Tylavsky FA \& Anderson JJ (1988) Dietary factors in bone health of elderly lactoovovegetarian and omnivorous women. American Journal of Clinical Nutrition 48, 842-849.

Wang J, Zhou J \& Bondy CA (1999) IGF-1 promotes longitudinal bone growth by insulin-like actions augmenting chondrocyte hypertrophy. FASEB Journal 13, 1985-1990.

Wolinsky I \& Fosmire GJ (1982) Calcium metabolism in aged mice ingesting a lysine-deficient diet. Gerontology 28, 156-162.

Yakar S, Rosen CJ, Beamer WG, Ackert-Bicknell CL, Wu Y, Liu JL, Ooi GT, Setser J, Frystyk J, Boisclair YR \& LeRoith D (2002) Circulating levels of IGF-1 directly regulate bone growth and density. Journal of Clinical Investigation 110, 771-781.

Yan L, Zhou B, Prentice A, Wang X \& Golden MH (1999) Epidemiological study of hip fracture in Shenyang, People's Republic of China. Bone 24, 151-155.

Zhang M, Xuan S, Bouxsein ML, von Stechow D, Akeno N, Faugere MC, Malluche H, Zhao G, Rosen CJ, Efstratiadis A \& Clemens TL (2002) Osteoblast-specific knockout of the insulinlike growth factor (IGF) receptor gene reveals an essential role of IGF signaling in bone matrix mineralization. Journal of Biological Chemistry 277, 44005-44012. 